\begin{tabular}{r}
\hline \hline 82.0 \\
https://doi.org/10.18485/msc.2018.47.2.ch20
\end{tabular}

Владимир В. ГВОЗДЕН*

Универзитет у Новом Саду

Филозофски факултет
Оригинални научни рад

Примљен: 28. 10. 2017.

Прихваћен: 27. 12. 2017.

\title{
ИДЕЈА О МУДРОЈ ЛУДОСТИ И БАХТИНОВ КОНЦЕПТ КАРНЕВАЛИЗАЦИЈЕ: КРИТИЧКО И КОНТЕКСТУАЛНО РАЗМАТРАњЕ
}

\begin{abstract}
Руски теоретичар Михаил Бахтин је карневал повезао са тренуцима кризе и друштвеним циклусима и посебно нагласио логику инверзије, својствену књижевној фигури мудре луде која се конституисала на прагу модерног доба. Ослоњен на новија истраживања (И. Мецлер, М. Харис, И. С. Гилус), овај рад је покушај критичког и контекстуалног приступа темељним Бахтиновим категоријама: идеја о мудрој лудости је постављена у историјски (економски, медицински, социјални) контекст њеног настанка, а концепт карневализације је доведен у везу са теолошким, интелектуалним, географским и социјалним аспектима празника луда. Према Бахтину, карневализација има значајну политичку последицу, јер људе ослобађа ропства према обичајима и хијерархијама и ствара нов поглед на живот, нужан за политичку промену. Па ипак, многобројни су они који, попут Умберта Ека, из савремене перспективе овај процес виде као облик друштвене контроле, као тек само још један сигурности вентил, привремени одушак помоћу којег се чува status quo. Узимајући у обзир како историјске тако и савремене амбиваленције концепата мудре лудости и карневализације, аутор на крају рада излаже покушај да се Бахтин чита contra Бахтин.

Кључне речи: лудост, ментална ометеност, празник луда, историзација, карневал, друштвена критика, контингенција, профанација, рано модерно доба, модерност.
\end{abstract}

Идеја о мудрој лудости спада у ред примитивистичких идеја, јер почива на претпоставци да постоји једноставније, непосредно знање помоћу којег се људска природа може еманциповати од вазда присутних коруптивних и смртно озбиљних процеса. Главно оруђе мудре лудости је смех, који се посматра као једина утеха пред животним тешкоћама. Психолози, као што је знано, смех описују „као инстинктивну и интуитивну, рефлексивну реакцију која је резултат психичког, емоционалног и интелектуалног подражаја", а антрополози су ритуално лудирање одавно повезали са идејом културе као такве (Вајт 1998: 33). Идеја о мудрој лудости се тумачи као израз човекових

*vladimir.gvozden@ff.uns.ac.rs 
самокритичких потенцијала и могућности опстанка чија је сврха да се оспоре постојећи животни обрасци и друштвено стање, али и да се превазиђу ситуације неслободе. С обзиром на то да се услови за испољавање поменутих потенцијала испољавају од памтивека, стиче се утисак да је релативистичка фигура мудре луде што подрива свеколику озбиљност учених историјска константа. Па ипак, она је, као име, везана за одређени тип односа према ауторитету, слободи, субјективности, знању и менталној ометености који је карактеристичан за рано модерно доба, односно за прелаз из средњег века у ренесансу. Стога је фигуру мудре лудости, насталу пре свега на темељу променљиве идеје о лудости, потребно историзовати, јер трансисторијски приступ води ка лепљењу хетерогених чињеница из различитих раздобља у целовиту слику која никада није постојала.

Наравно, „промене у речима сведоче о променама у ставовима” (Мецлер 2016: 31), па тако један новији истраживач феномена менталних поремећаја кроз историју оправдано истиче да „нема начина да поуздано знамо да ли би неко кога су у 16. столећу називали лудаком био, кад бисмо га преместили у времену, назван 'приглупим' у 18. столећу или 'имбецилом' деведесетих година 19. столећа, или пак 'умерено или благо ретардираном особом' шездесетих година 20. столећа” (Макдона 2008: 6), или у наше време „особом са интелектуалним сметњама". Први услов за појаву фигуре мудре лудости било је успостављање поделе на природну и вештачку лудост које се лагано одвијало у раздобљу од 11. до 15. столећа, кад вештачка луда коначно задобија смисао захваљујући пре свега фигурама драмске (литерарне) и дворске луде (Кајзер 1963: 6). У дискусијама из поменутог раздобља преовлађује увид да природна луда не може да функционише нормално због свог физичког, менталног или емоционалног стања, док вештачке луде „подражавају ограничења природне луде и сходно томе имају дозволу да излажу подсмеху друге припаднике друштва” (Џеник 1998: 1). Мудра луда преузима понашање природне луде: као дете природе, она крши друштвене конвенције и има развијене апетите и жеље (Кајзер 1963: 6); она брбља и раскалашно се понаша, што се оправдава недостатком језичких и рационалних способности природне луде (Мецлер 2016: 205). Мудра, односно вештачка луда је симболички глумац што наговештава слику света као сцене, која најпознатији израз има код Еразма, Раблеа и Шекспира; мудрост лудости означава способност изналажења начина да играмо у комаду живота. Упркос разликовању природне и вештачке луде (stultus), оне ипак имају нешто заједничко: деле идеју да њихово лудило (stultitia) треба да буде нешкодљиво, ненасилно, у основи мирољубиво, док су насилни ,лудаци” означавани као furiosi или frenetici (Мецлер 2016: 199).

Дакле, уочи конституисања литерарне фигуре мудре луде, на коју се ослања Михаил Бахтин, природно лудило повезивано је са физичким, менталним и емоционалним стањем које је ваљало да, ради одређених циљева, подражава вештачка луда. Амбивалентне реакције према таквом опонашању су, како се чини, део целокупне структуре бинарних опозиција које се отварају поводом мудре лудости, али и поводом поретка модерне моћи 
као знања: нормално/ненормално, разум/страст, мудрост/лудост, глава/срце, поредак/хаос, ред/неред, мушко/женско, светлост/тама, култура/анархија, цивилизација/примитивизам, вештачко/природно, умереност/прекомерност, самоконтрола/разуданост, краљ/луда, Велики пост/карневал. Према неким тумачењима, луда, будући да иступа против опозиционих дихотомија логоцентризма, има протодеконструктивну улогу која показује да све ствари унутар себе садрже трагове других ствари (Џеник 1998: 19). Као што је познато, Бахтин је на сличан начин посматрао глас трга који се смеје; тај глас и није глас опозиције, већ глас који подрива читав хијерархијски поредак (Џеник 1998: 19; видети и Вилефорд 1969: 108). Ипак, мора се узети у обзир да су модалитети мишљења производ културе: данас је познато да средњовековни клерик (интелектуалац) није имао потешкоће са контрадикцијама, он је ,једну монолитну 'истину' могао да растави у многобројне 'истине', у складу са божанским или људским, природним или оностраним модалитетом разумевања" (Мецлер 2016: 7).

Сходно томе, требало би, кад је о подели на природне и вештачке лудаке реч, имати у виду неколико контекстуалних напомена које, како се чини, упућују на то да је ова подела, кад се посматра кроз релацију прелаза средњи век - модерно доба, увек унапред деконструисана: док се данас идеја менталних поремећаја везује за душевно стање, средњовековни медицински текстови ,,разликују се од модерног поступка одвајања менталних и бихевиоралних поремећаја с једне стране, и физичких, с друге; средњовековни текстови, како се чини, нису разликовали менталне и физичке поремећаје и, што је кључно, готово све врсте менталних поремећаја приписивали су слому неког физиолошког процеса или су барем веровали да су њиме посредовани" (Кемп 1990: 114). Исто тако, нема доказа да су „средњовековни писци правили јасну разлику између менталне болести и менталне ометености” (Мецлер 2016: 39). Поврх тога, мора се узети у обзир да се „у смислу чврстог идентитета или означавања особе чини да су средњовекони облици опхођења према интелектуалној ометености били много флуиднији од модерних" (Мецлер 2016: 230). Док се данас дијагноза лепи за човека, у средњем веку је интелектуално ометена особа већи део времена сматрана нормалном (Мецлер 2016: 230). Тиме се може тумачити и чињеница да на прагу раног модерног доба о лудама много више сведоче теолошки и филозофски текстови, него медицински, премда је и овде упутно напоменути да границе „између теологије, филозофије и психологије какве су данас тада нису постојале” (Мецлер 2016: 84). Стога и не би требало да чуди што је главна обрада овог феномена била књижевна (књижевност је и сама имала „интердисциплинаран” положај): ваздизање лудости у књижевности било је, како се тврди, толико снажно да је готово сасвим прикрило социјалну проблематику менталне ометености у средњем веку (Мецлер 2016: 3). Ову фигуру створили су највећи раномодерни генији прераде постојећих материјала (Брант, Еразмо, Шекспир, Сервантес), али се сматра да је Раблеов роман Гаргантуа и Пантагруел,,заувек променио позносредњовековно разумевање лудости и преставио је у модерној форми” (Кенеди 1998: 370). Морамо, дакле, узети у обзир чињеницу да је 
фигура лудости поникла на тлу књижевних текстова, а не у оквирима народне културе, како то приказује Бахтин.

У књижевном контексту, лудост је готово немогуће дефинисати - као што нас упозорава Еразмова Стултиција; разлог за то је „мноштво критерија за класификацију” (Џеник 1998: 2). Оваква флуидна идеја мудре лудости - која корене у писаним текстовима има у Одбрани Сократовој, у општим местима из Кьиге проповедникове (бескрајан је број лудака) и посланицама апостола Павла - налази се и у темељу карневалске културе средњег века и раног модерног доба. Према Вики Џеник, фикционална, књижевна мудра луда признаје и препознаје како сопствене жеље и слабости, тако и жеље и слабости других, њено арлекинско, шарено одело је обележје не-разума из којег потиче, а њене главне особине су следеће: одбија идентификацију у времену и простору (необично или никакво порекло, необично или незнано место рођења и сл.); обитава на рубовима маште и стварности; тешко ју је дефинисати не само зато што је она израз парадокса, већ и зато што је њен ум обузет противречностима и парадоксима; упркос рубном положају, она има необичне моћи у стварном свету; усредсређена је на телесне функције (храна, пиће, секс...); говори на необичан начин у квантитативном и квалитативном смислу, другачије од остатка друштва (Џеник 1998: 8-12).

Противећи се владајућој схоластици, егзалтирани једноставним хришћанством и начином живота који подражава Христову лудост, концепт луде у Христу развијали су многобројни аутори средњег века (Гргур Велики, Скот Еригена, Фрањо Асишки, Јакопоне де Тоди, Ремон Љуљ, Тома Кемпијски, Никола Кузански) (Кајзер 1963: 9). У једном могућем читању хришћански оквир је наметао супротстављање појавном свету, његовим хијерархијама и нормама, јер је Христовим доласком свет окренут наопачке. На темељу оваквих ставова у Светом писму, луда је тражила легитимитет за иконокластичке иступе који су циљали на разобличавање темеља на којима је изграђена власт, постојећи систем моћи који, као и сви системи моћи, пре свега жели да остави утисак да је немогућ, па чак и фаталан другачији поредак. Луда напада овако изграђене хоризонте нормалности и настоји да прошири могућности политичког деловања, што је темељ и каснијих позитивних оцена карневалске културе. Луда се представља као сувише проста, неспособна за поимање и прихватање сложених и суптилних система моћи, сувише глупа да не би видела сирову истину с оне стране владајуће идеологије. Наравно, оваква лудост је само фигура, што је највидљивије код Еразма и Раблеа.

Али пре него што се вратимо на ту копчу, потребно је поставити још једно питање: зашто је идеја мудре лудости доживела свој највећи успон паралелно и унутар успона европског хуманизма на прагу модерног доба? Ту је, разуме се, важан сократовски моменат. Наиме, оксиморон „мудра луда" се може читати у оба правца: луда је мудра, мудрац је луд. Ова тема присутна је већ у антици, рецимо код Хераклита који је, колико је познато, први изразио запажање да много учења не води мудрости (фрагм. 40). Ипак, Сократ је класичан архетип мудре луде што критикује лудост мудраца који немају свест о властитом незнању. Идеја мудрости (sapientia) луде увек се 
налази у супротности са знањем (scientia) учених или са мудрошћу у светским питањима (sapientia mundana). Али, осим интелектуалног, важан је и економски моменат: Ирина Мецлер на концу књиге Луде или идиоти? Интелектуална ометеност у средњем веку примећује следеће: „сигурно није случајно то што је у исто време, и у истим географским областима, држање дворских луда постало популарно и опште место као и 'држање' професионалних интелектуалаца, хуманиста” (Мецлер 2016: 232-233). Ово се може тумачити чињеницом да се већ на самом прагу модерног доба јавила, унутар поредака дискурса, слутња да је у општој хијерархији моћи економска моћ ипак надређена интелектуалним моћима што, упркос развоју идеја о људском достојанству и аутономији, ствара разноврсне облике класне зависности и друштвених разлика.

Ослушкујући критичке импулсе позног средњег века и ренесансе, Михаил Бахтин сматра да је оно што је луда била у свакодневици (а што је ипак упитно), карневал био унутар ширих временских захвата: нека врста цезуpe, реза, простора и времена слободе у којем су важеће друштвене норме биле суспендоване. Руски теоретичар је, као што је познато, карневал (или тачније, идеју о карневалу) повезао са тренуцима кризе и друштвеним циклусима и посебно нагласио логику инверзије својствену фигури мудре луде: карневал карактерише логика „изокренутости”, он је други свет народне културе и ствара се у извесној мери као пародија обичног, то јест ванкарневалског живота, као „svet naopako” (Бахтин 1978: 18). Бахтин идеју карневала везује за празник луда (Fête des Fous), који је свој легитимитет заиста налазио у инверзији, између осталог у стиховима из Јеванђеља по Луки (1:53), које изговара Марија: „Гладне напуни блага, и богате отпусти празне” (превод В. Караџић). Важно је, међутим, приметити да се „празник луда није јавио у контексту друштвеног нереда и опадања цркве, већ у контексту економског просперитета, интелектуалног процвата и иновација у архитектури и литургијској пракси" (Харис 2011: 66), чиме новозаветна дијалектика глади и блага, богатства и празнине још више добија на значају. Овде искрсава још једна важна подела. Библијска традиција препознаје две врсте лудака: прва врста пориче постојање и власт Бога (јавља се, на пример, у Псалмима Давидовим, у Къизи проповедниковој); друге је одабрао Бог због њихових недостатака према овоземаљским мерилима (ову идеју је артикулисао Св. Павле). Ако је нешто у празнику луда било обрт, тај обрт је био везан за одређени контекст и заправо се темељио на давању почасти лудама нижег реда по овоземаљским мерилима (Харис 2011: 67). Празник луда није тек пука пролазна слобода поклоњена нижем свештенству или народу, он слави Христово „лудо” понашање, укључујући његову спремност да се унизи тако што преузима људско обличје и трпи физички бол (Харис 2011: 67). Све у свему, како се истиче у истраживањима овог празника: „Празник луда је добио то име не од луда које се боре против Бога, већ од луда које, попут Христа, Бог воли због њиховог нижег статуса" (Харис 2011: 67).

Упркос томе, Бахтин, како се чини, комбинује диспаратне изворе у синхрони наратив, па у празницима луда у први план ставља смех као победу над 
страхом и препознаје шаљив и лакрдијашки карактер који означава „otvoreno priznavanje drugog prazničnog života srednjovekovnog čoveka” (Бахтин 1978: 89). Дакле, Бахтинова социјално-политичка теорија карневализације тврди да карневалски импулс наводи на противљење ауторитету (Кочис 1998: 101-102). Ипак, овде се у једначини побуне јавља неизрачунљива непозната: проблем је што руски теоретичар тотализује празник луда и претвара га у доживљај света средњовековног човека, премда се мора имати на уму да се празник луда никада није удаљавао од подручја сакралног (Леве 1983: 20), односно од једног прилично уског слоја људи у друштву, и то искључиво у појединим француским градовима и тек понегде у Енглеској. А кад размишљамо о ослобађајућем потенцијалу карневала, морамо узети у обзир да се он у изворима никада не критикује због интелектуалне и теолошке подлоге, већ због претерано раскалашног понашања нижег свештенства током празника (Кочис 1998: 99). Осим тога, Бахтин одваја средњовековни живот у два модалитета егзистенције, с једне стране је озбиљна феудално-црквена власт, а са друге народ који се смеје: „Srednjovekovni ljudi sudelovali su podjednako u dva života - zvaničnom i karnevalskom, - u dva aspekta sveta - ozbiljnom, punom strahopoštovanja i smehovnom. Ta dva aspekta postojala su istovremeno u njihovoj svesti” (Бахтин 1978: 111). Но управо кад је реч о празнику луда јасно је да ова дихотомија не стоји, јер учесник у том догађају није био народ са трга који се смеје, а заправо ни место радње није био трг. Током овог догађаја бирао се, рецимо, бискуп луда који је оличавао и подражавао стандардне црквене ритуале, остајући унутар религијске сфере. Наравно, бискуп луда има одређени критички потенцијал: пошто пародира и симбол моћи и елементе ритуала, он свакако разоткрива и облике злоупотребе власти, али се мора посматрати као показатељ преокупација једне друштвене класе, нижег свештенства (које, још једном ваља рећи, ни у ком случају није репрезент народа). Смех током овог празника не само што се збивао у цркви, већ је био део црквене литургијске праксе (Кочис 1998: 99), што само значи да су кроз ову фигуру најнижи у црквеној хијерархији могли да изразе потиснути бес и озлојеђеност и да тако, избацивањем властитих фрустрација, допринесу одржању друштвеног поретка (Кочис 1998: 102). Остаје чињеница да је уздизање нижег свештенства на место вишег било „парадоксално уздизање ниског које и даље остаје ниско, не ниског које постаје високо" (Гилус 1990: 42). Ако је лудост и економска и класна категорија, чак и занимање (Мецлер 2016: 187), јасно је да преузимање њеног обличја остаје везано за поредак. Постоје данас чак и тумачења која тврде да циљ ових празника није ни било ослобађање од тензија већ стварање узбуђење код учесника -ниже свештенство одржавало је овај празник само због пуке забаве (Гилус 1990: 46).

Наравно, могуће је данас, поводом Бахтинове идеје, размишљати о посебном типу контингенције који настаје унутар привремености карневалске културе, утемељене на лудости, лакрдији и неразуму, али и даље остаје отворено питање „трансформације ове маргиналне парадигме у темељну парадигму (root paradigm)" секуларне културе (Гилус 1990: 103) на којој он инсистира у тврдњи да је карневал једини празник који „,narod priređuje sam 
sebi, narod tu ne dobija ništa, ni pred kim ne pada ničice, oseća se kao gospodar" (Бахтин 1978: 266). Стиче се утисак да „свет наопачке постаје норма” (Еко 1984: 3). Умберто Еко указује на то да оваква теорија има велику шансу да буде популарна, али да постоји проблем са њом: на несрећу, она је потпуно погрешна и то не само зато што, како је напоменуто, ниже свештенство није народ, неколико градова у Француској нису свет, а црква није секуларни простор, већ и из следећих разлога:

Ако би она била тачна, било би немогуће објаснити зашто је моћ (било која друштвена и политичка власт кроз векове), употребљавала концепцију хлеба и игара (circenses) да умири масу; зашто су најрепресивније диктатуре увек цензурисале пародије и сатире али не и лакрдије; зашто је хумор под сумњом, а циркус невин; зашто су данашњи масовни медији, ван сваке сумње средства друштвене контроле [...], утемељени углавном на забавном, на смешном, то јест, на непрекидној карневализацији живота (Еко 1984: 7).

Уистину, луда је „комичан карактер par excellence” (Кајзер 1963: 11). Литерарно посматрано, у лудином смеху се зрнце мудрости крије у иронији, али да ли је то могуће у стварности? Постоје одређени антрополошки увиди који показују „да везе проистекле из шале могу да поспеше социјалну кохезију” (Вајт 1998: 35). Па ипак, смех је често само емоционални одушак којим се ослобађамо такозване негативне енергије и компетитивних фрустрација. Комика није вредност по себи, јер она може бити, како подвлачи Еко, и расистичка, односно смех може да „изолује странца, да оправда убиство, па чак и да покрене рат" (Вајт 1998: 35). Према Бахтину, карневализација има значајну политичку последицу, јер људе ослобађа ропства према обичајима и хијерархијама и ствара нов поглед на живот, нужан за политичку промену. Па ипак, многобројни су они, попут Ека, који овај процес виде као облик друштвене контроле, као тек само још један сигурности вентил, привремени одушак помоћу које се чува status quo (Кенеди 1998: 373). Осим тога, увек постоји изазов историзације: чини се да концепт карневализације, као ни фигура мудре лудости, није лако преносив у стварност, сасвим сигурно не толико лако како се креће кроз повест књижевности.

Бахтинова теорија карневализације, утемељена на идеји мудре лудости подложна је, дакле, озбиљним примедбама. Остаје ли, упркос томе, простора да поставимо питање постоји ли у Бахтиновом повезивању мудре лудости и теорије карневала нешто више, неки додатни проблем? Ту нам је од помоћи једна идеја коју образлаже Ђорђо Агамбен у књизи Отворено: човек и животињ $a$. Наиме, у идеји мудре лудости се још једном показује да је човек, како би рекао Агамбен, вазда простор и резултат непрестаних подела и цезура (Агамбен 2014: 18). Рана модерна мисао осетила је да homo „nema vlastitu prirodu i da ostaje razdvojenost između nebeske i zemaljske prirode, između životinjskog i ljudskog - zato je njegovo bivstvovanje svagda manje i više nego on sam" (Агамбен 2014: 29). Не би ваљало овде поћи путем испразног морализма, нема спољашње моралне позиције као што нема ни трансисторијске позиције, јер и субјект исказивања синтагме „Квинтесенција прашине” из чувеног Хамлетовог монолога неминовно мора бити човек. Хуманистичко откриће човека, како закључује Агамбен, ,jeste otkriće njegova pomanjkanja 
samome sebi, nepopravljiva odsutnost dignitas pri njemu” (2014: 30). Стога се и мудра лудост може ишчитавати као слика напетости унутар идеала човека, јер говори о ироничној дистанци спрам људскости која се не може адекватно попунити ни са једне стране.

Зато се Бахтин, via Агамбен, можда може читати и contra Бахтин. Наиме, ако се не схвати било морализаторски било популистички (чему је сам Бахтин, дуалистички наклоњен, на тренутке склон), карневализација је мноштвени облик инверзије на којој израста и идеја мудре лудости укључујући обе поменуте равни: инхерентни недостатак својствен идеји о hoто, којем се увек мора нешто додати (homo sapiens или insipiens) у циљу препознавања оног људског у њему; али и могућност политике која упућује на стварање контингентне заједнице - супротно владајућим класификацијама и структурама - унутар карневалског времена које је би ипак морало бити уписано у исту раван у коју и официјелно време. У социјалноонтолошком смислу, карневализација би било политичко структурирање мноштва које је ван контроле система моћи, али које користи продуктивне аспекте тог система (примери оваквих контингентних структурирања данас могу бити покрети Окупирај Волстрит и Анонимуси, као и непрофитна организација Викиликс). У овом концепту до изражаја долази подељеност човека, која се очитује у гротескном реализму, као и пародија која такође настаје на међи претходно постојећих образаца и нових могућности језичке политике.

Овде је још једном потребно подвући да су идеју мудре луде стварали најобразованији људи раног модерног доба (Брант, Еразмо, Томас Мор, Дирер, Рабле), друштвени инсајдери незадовољни правцима друштвеног развоја, критичари корупције, поборници некакве политичке другости унутар чврстих хијерархијских поредака којима су сами припадали. Ако је срећа везана за Кантов парадокс (да је услов среће ум), онда постаје уистину логично да се друштвени критичар повлачи на терен мудре лудости, јер она омогућава останак на терену иманенције, на тлу човекове нестабилности, и отвара могућност да се буде унутар друштва и разделовљене људскости и да се то друштво и таква људскост критикују, као што и показују заводљиви литерарни примери настали на прагу модерног доба. Парадоксална мудра лудост изражава „,nemogućnost jezika da dosegne stvar i nemogućnost stvari da pronađe svoje ime" (Агамбен 2010: 56) и омогућава да се у критици стварности не доспе у сфере идеализоване другости. Ово је кључно за разумевање еманципаторских капацитета карневалске културе у профанацији света, онако како потоњу разумева Агамбен: „Профанисати значи отворити могућност посебног облика нехајности који запоставља раздојеност или је, пак, употребљава на посебан начин" (Агамбен 2010: 86). Наизглед литерарни проблем мудре лудости нас, како се чини, води ка раномодерној и постмодерној граници и сведочи о неразрешеном расцепу модерног политичког субјекта који je осећао Бахтин: наиме, књижевност као алегорија политичког, губећи утеху институционализоване религије (логоса), нову утеху налази у пародијским и иронијским профанацијама, које сведоче да је земаљско знање недостижно, а да се ипак мора трагати за њим тако што се отвара могућност простора 
и времена деловања недефинисаног мноштва, које није структурирано око некаквог (или било каквог) центра као темеља промене.

\section{ЛИТЕРАТУРА}

Агамбен 2014: Đ. Agamben, Otvoreno: čovjek i životinja, Čačak: Gradac.

Агамбен 2010: Đ. Agamben, Profanacije, Beograd: Rende.

Бахтин 1978: M. Bahtin, Stvaralaštvo Fransoa Rablea i narodna kultura srednjega veka i renesanse, Beograd: Nolit.

Вилефорд 1969: W. Willeford, The Fool and Its Scepter, Evanston, IL: Northwestern University Press.

Гилус 1990: I. S. Gilhus, Carnival in Religion: The Feast of Fools in France, $N u$ men, vol. 37, no. 1, 24-52.

Еко 1984: U. Eco, The Frames of Comic Freedom, in: U. Eco, V. V. Ivanov, Monica Rector, Carnival!, (ed.) Thomas A. Seboek, Dublin, New York, Amsterdam: Mouton Publishers, 1-10.

Kajzep 1963: W. Kaiser, Praisers of Folly: Erasmus, Rabelais, Shakespeare, Cambridge, Mass.: Harvard University Press.

Кемп 1990: S. Kemp, Medieval Psychology, New York: Greenwood Press.

Кенеди 1998: W. J. Kennedy, François Rabelais, in: V. K. Janik, Fools and Jesters in Literature, Art and History: A Bio-Bibliographical Sourcebook, Westport, Connecticut \& London: Greenwood Publishers, 370-375.

Кочис 1998: S. Cochis, The Bishop of Fools (France and England, 1180s-1600s), in: V. K. Janik, Fools and Jesters in Literature, Art and History; A BioBibliographical Sourcebook, Westport, Connecticut \& London: Greenwood Publishers, 97-105.

Леве 1983: Maurice Lever, Le sceptre et la marotte, Paris: Fayard.

Макдона 2008: P. McDonagh, Idiocy: A Cultural History, Liverpool: Liverpool University Press.

Мецлер 2016: I. Metzler, Fools and Idiots? Intellectual Disability in the Middle Ages, Manchester: Manchester University Press.

Bajт 1998: C. Todd White, The Anthropology of Fools, in: V. K. Janik, Fools and Jesters in Literature, Art and History: A Bio-Bibliographical Sourcebook, Westport, Connecticut \& London: Greenwood Publishers, 33-40.

Харис 2011: M. Harris, Sacred Folly: A New History of the Feast of Fools, Ithaca \& London: Cornell University Pres.

Џеник 1998: V. K. Janik, Introduction, Fools and Jesters in Literature, Art and History; A Bio-Bibliographical Sourcebook, Westport, Connecticut \& London: Greenwood Publishers, 1-21. 
THE IDEA OF WISE FOOL AND BAKHTIN'S CONCEPT OF CARNIVALESQUE: CRITICAL AND CONTEXTUAL APPROACH

\begin{abstract}
(Summary)
Russian theorist Mihail Bakhtin in his Rabelais and His World linked the carnival with the moments of crisis and social cycles, and especially emphasized the logic of inversion that is characteristic of the literary figure of wise fool constituted on threshold of modern times. Relying on recent research by Irene Metzler and Max Harris, this paper is an attempt at a critical and contextual approach to Bakhtin's basic categories: the idea of wise fool is re-situated in the historical (economic, medical, social) context of its creation, and the concept of carnivalesque has been linked to theological, intellectual and social aspects of the Feast of Fools (Fête des Fous). According to Bakhtin, carnivalesque has a significant political effect, because it could free people from slavery of customs and hierarchies and can create a new view of life, necessary for political change. Nevertheless, there are many who, like Umberto Eco, see this process from a modern perspective as a form of social control, as just another safety valve, a temporary exit by which status quo is kept. Taking into account the historical as well as contemporary ambivalence of the concepts of wise fool and carnivalesque, the author at the end of the paper exposes an attempt to read Bakhtin contra Bakhtin.
\end{abstract}

